\title{
Critical nitrogen dilution curves and productivity assessments for plant cane
}

Augusto C. de A. Santana ${ }^{1}$, Emídio C. A. de Oliveira ${ }^{2}$, Vinícius S. G. da Silva ${ }^{3}$, Renato L. dos Santos ${ }^{3}$, Magda A. da Silva ${ }^{1} \&$ Fernando J. Freire ${ }^{2}$

${ }^{1}$ Universidade Federal Rural de Pernambuco/Programa de Pós-Graduação em Ciência do Solo, Recife, PE, Brasil. E-mail: augusto.arruda26@yahoo.com.br ORCID: 0000-0002-0377-033X; mf.silva@agronoma.eng.br - ORCID: 0000-0003-3821-8526

${ }^{2}$ Universidade Federal Rural de Pernambuco/Departamento de Agronomia, Recife, PE, Brasil. E-mail: emidio.oliveira@ufrpe.br (Corresponding author) - ORCID: 0000-0002-9283-7910; fernandojfreire@uol.com.br - ORCID: 0000-0002-3264-712X

${ }^{3}$ Instituto Federal de Educação, Ciência e Tecnologia de Pernambuco, Campus Vitória de Santo Antão, Vitória de Santo Antão, PE, Brasil. E-mail: vinicius.agro2008.1@gmail.com - ORCID: 0000-0003-3094-5884; renato.santos@vitoria.ifpe.edu.br - ORCID: 0000-0001-7396-1759

\begin{abstract}
Nitrogen is the most limiting nutrient for the development of sugarcane and particularly the use of more productive and demanding varieties, for which the doses of nitrogen fertilization necessary during the plant cane cycle may be underestimated and the critical levels of nitrogen in the leaf may be modified. The objective of this study was to determine the critical nitrogen dilution curve (CNDC) for leaves, evaluate the aboveground dry mass production (DM) and productivity of two varieties fertilized with $\mathrm{N}$ in the plant cane cycle. The study was conducted under field conditions, evaluating two sugarcane varieties RB92579 and RB867515, fertilized with seven doses of $\mathrm{N}\left(0,30,60,90,120,150\right.$ and $\left.200 \mathrm{~kg} \mathrm{ha}^{-1}\right)$. The varieties and doses were arranged in randomized blocks and analyzed in the $2 \times 7$ factorial scheme. It was found that the nitrogen concentration in the leaf decreased with four repetitions increase in DM yield and adjusted an exponential model, which enabled to estimate the critical levels of 13.03 and $12.46 \mathrm{~g} \mathrm{~N} \mathrm{~kg}^{-1}$ dry matter in the varieties RB92579 and RB867515, respectively. The plant cane cycle were observed to respond positively to nitrogen fertilization, with increase of $18.66 \%$ in tons of stalk per hectare (TSH) in response to the application addition of up to $129.45 \mathrm{~kg} \mathrm{~N} \mathrm{ha}^{-1}$. The variety RB92579 showed the lowest dilution of the critical nitrogen concentration, the highest production of DM and higher stalk yield, and accordingly is considered to be the more efficient of the two varieties with respect to nitrogen fertilizer utilization.
\end{abstract}

Key words: Saccharum spp., nitrogen fertilization, aboveground dry matter, variety

\section{Curvas de diluição do nitrogênio crítico e produtividade da cana planta}

RESUMO: O nitrogênio $(\mathrm{N})$ é o nutriente mais limitante ao desenvolvimento da cana-de-açúcar e com a utilização de variedades mais produtivas e exigentes, as doses utilizadas na adubação nitrogenada na cana planta podem estar subestimadas e os teores críticos de $\mathrm{N}$ na folha poderão sofrer modificações. O objetivo da pesquisa foi determinar a curva de diluição dos teores críticos de N (CNDC) na folha, avaliar a produção da massa seca da parte aérea $(\mathrm{ADM})$ e a produtividade de duas variedades de cana-de-açúcar em relação à adubação nitrogenada. A pesquisa foi realizada em condições de campo, sendo avaliadas as variedades RB92579 e RB867515, quando adubadas com sete doses de $\mathrm{N}\left(0,30,60,90,120,150\right.$ e $\left.200 \mathrm{~kg} \mathrm{ha}^{-1}\right)$. As variedades e doses de $\mathrm{N}$ foram dispostas em blocos casualizados com quatro repetições sob o esquema fatorial de $2 \times 7$. O teor de $\mathrm{N}$ na folha reduziu com o aumento da ADM e se ajustou ao modelo exponencial que permitiu estimar os teores críticos de 13,03 e 12,46 $\mathrm{g} \mathrm{de} \mathrm{N} \mathrm{kg}^{-1}$ de matéria seca nas variedades RB92579 e RB867515, respectivamente. A cana planta respondeu positivamente à adubação nitrogenada e aumentou em $18,66 \%$ a tonelada de colmos por hectare $(\mathrm{TCH})$ com adição de até $129,45 \mathrm{~kg} \mathrm{ha}^{-1}$ de N. A variedade RB92579 apresentou menor diluição do teor crítico do N, maior produção de ADM e maior produtividade de colmos, sendo considerada mais eficiente na utilização do $\mathrm{N}$-fertilizante.

Palavras-chave: Saccharum spp., adubação nitrogenada, matéria seca da parte aérea, variedades 


\section{INTRODUCTION}

Nitrogen $(\mathrm{N})$ transformations within the soil-plantatmosphere system contribute to $\mathrm{N}$ losses and consequently reduce the availability of this nutrient to plants. In sugarcane, for example, $\mathrm{N}$ fertilizer utilization tends to be low and does not exceed 50\% in the plant cane cycle (Franco et al., 2015). In this production cycle, the lower $\mathrm{N}$ supply can reduce aboveground dry matter by $92 \%$, root growth by $82 \%$, and overall productivity by up to $25 \%$ (Franco et al., 2010; Vale et al., 2011).

However, despite the importance of $\mathrm{N}$ in the sugarcane cycle, there is still a lack of consensus regarding the effects on $\mathrm{N}$ fertilization in the first crop cycle (plant cane) with respect to crop growth and development, and studies rarely take into account the variety used.

With advances in genetic crop improvement and the increasing use of more $\mathrm{N}$-demanding varieties (Oliveira et al., 2016), linear increases in productivity have been observed for the plant cane cycle concomitant with increases of up to $300 \%$ in $\mathrm{N}$ fertilization, which is commonly applied at doses higher than $100 \mathrm{~kg} \mathrm{~N} \mathrm{ha}^{-1}$ (Fortes et al., 2013).

With the adoption of new varieties, application of higher amounts of $\mathrm{N}$ fertilizer, and higher sugarcane biomass production, it is speculated that the $\mathrm{N}$ concentration in plant tissues, considered to be an essential factor contributing to optimal plant development, may differ from that of currently cultivated varieties (Santos et al., 2013). This variation suggests that the quantities of $\mathrm{N}$ absorbed are determined by the amount of biomass produced during crop development (Oliveira et al., 2013).

This relationship in turn indicates the need to determine the critical level of $\mathrm{N}$ that promotes maximum biomass production at different growth stages (Oliveira et al., 2013). Thus, the objective of the present study was to determine the dilution curve of the critical $\mathrm{N}$ concentrations in sugarcane leaves in relation to the aboveground biomass, as well as to evaluate the yield of accumulated dry mass in aboveground parts (ADM) and the productivity of two sugarcane varieties fertilized with different $\mathrm{N}$ doses in the plant cane cycle.

\section{Material ANd Methods}

This study was conducted from November 2015 to November 2016 in the agricultural area of Usina São José S/A, located in the municipality of Abreu e Lima ( $7^{\circ} 49^{\prime} 09.61^{\prime \prime} \mathrm{S}$, $35^{\circ} 04^{\prime} 11.14^{\prime \prime} \mathrm{W}$ and altitude $128 \mathrm{~m}$ ) along the Northern Coast of the State of Pernambuco, Brazil. The climate according to the Koppen classification is characterized as Am's (tropical humid), with transition to type As' (pseudo-tropical), with an average temperature of $24^{\circ} \mathrm{C}$ (Alvares et al., 2013). During the experimental period, the average accumulated rainfall was $1,476.8 \mathrm{~mm}$. To ensure plant germination, it was maintained an irrigation depth of $30 \mathrm{~mm}$.

The soil in the experimental area is classified an Oxisol, and has the following properties: $\mathrm{pH}\left(\mathrm{H}_{2} \mathrm{O}\right)=6.0$; $\mathrm{M} . \mathrm{O}=$ $21.9 \mathrm{~g} \mathrm{~kg}^{-1} ; \mathrm{P}$ (Mehlich-1) $=3.0 \mathrm{mg} \mathrm{dm}^{-3} ; \mathrm{K}^{+}($Mehlich-1 $)=0.15$ $\mathrm{cmol}_{\mathrm{c}} \mathrm{dm}^{-3} ; \mathrm{Ca}^{2+}=3.30 \mathrm{cmol}_{\mathrm{c}} \mathrm{dm}^{-3} ; \mathrm{Mg}^{2+}=0.80 \mathrm{cmol}_{\mathrm{c}} \mathrm{dm}^{-3}$;
$\mathrm{Al}^{3+}=0 \mathrm{cmol}_{\mathrm{c}} \mathrm{dm}^{-3} ; \mathrm{H}+\mathrm{Al}=2.20 \mathrm{cmol}_{\mathrm{c}} \mathrm{dm}^{-3} ; \mathrm{Fe}^{2+}=119.29 \mathrm{mg}$ $\mathrm{dm}^{-3} ; \mathrm{Cu}^{2+}=7.60 \mathrm{mg} \mathrm{dm}{ }^{-3} ; \mathrm{Mn}^{2+}=5.30 \mathrm{mg} \mathrm{dm}{ }^{-3} ; \mathrm{Zn}^{2+}=20.30$ $\mathrm{mg} \mathrm{dm}^{-3} ; \mathrm{CEC}_{\text {potential }}=6.45 \mathrm{cmol} \mathrm{dm}_{\mathrm{c}} \mathrm{dm}^{-3} \mathrm{~V}=66.34 \%$; Argila $=417.0 \mathrm{~g} \mathrm{~kg}^{-1}$; Silt $=103.0 \mathrm{~g} \mathrm{~kg}^{-1}$; and Sand $=480.0 \mathrm{~g} \mathrm{~kg}^{-1}$. The characterization of these soil physicochemical properties was performed prior to commencing the experimental procedures, using samples collected from the $0-0.20 \mathrm{~m}$ soil layer and following EMBRAPA (2017) chemical and physical analysis protocols.

The experimental treatments were arranged in a randomized block design, with four repetitions, under a $2 \times 7$ factorial scheme, consisting of two varieties of sugarcane (RB867515 and RB92579) and seven doses of $\mathrm{N}(0,30,60,90,120,150$, and $200 \mathrm{~kg} \mathrm{ha}^{-1}$ ) as urea source applied in a single dose at the base of the planting furrow. The plots comprised six $10 \mathrm{~m}$ long rows with a $1.0 \mathrm{~m}$ spacing between rows. The area used for analytical purposes was delimited by the four $8 \mathrm{~m}$ long central rows (discarded plants growing in the $1 \mathrm{~m}$ lengths at each row end), comprising a total area of $32 \mathrm{~m}^{2}$.

The sugarcane varieties were selected based on their high adaptability, productivity and representativeness in Brazil (Silveira et al., 2012). All plots received planting fertilizer at the base of the row, by applying $120 \mathrm{~kg} \mathrm{~K}_{2} \mathrm{O} \mathrm{ha}^{-1}$ in the form of potassium chloride $(\mathrm{KCl}), 150 \mathrm{~kg} \mathrm{P}_{2} \mathrm{O}_{5} \mathrm{ha}^{-1}, 65 \mathrm{~kg} \mathrm{~S} \mathrm{ha}^{-1}$ in the form of simple superphosphate (SFS), and $370 \mathrm{~g}$ of S, 10 $\mathrm{g}$ of $\mathrm{B}, 20 \mathrm{~g}$ of $\mathrm{Cu}, 500 \mathrm{~g}$ of $\mathrm{Mn}$ and $80 \mathrm{~g} \mathrm{Zn} \mathrm{ha}^{-1}$ added in the form of salts.

To determine biomass production, it was the aboveground parts of plants growing in a linear meter within the demarcated core area of the plots were collected. Collections were made at 45, 90, 135, 235 and 300 days after planting (DAP), constituting five evaluations during the entire plant cane cycle.

For sampling, it was adopted the methodology described by Oliveira et al. (2010). The samples were separated into tops, leaves and stalks, the tops consisting of the cartridge and the leaf +3 . As leaf components, the dry and green leaves from the leaf +2 were used, and after the removal of the tops and leaves, the remainder was considered stalks.

The accumulation of dry matter (ADM) was determined from the sum of top, leaf and stalks weights measured in the field and expressed in terms of $\mathrm{Mg} \mathrm{ha}^{-1}$. The plant material was subsequently crushed in a fodder chopper and sub samples were removed to determine the wet mass. The moist sub samples were dried in an oven with forced air circulation at $65^{\circ}$ for $72 \mathrm{~h}$ for determinations of moisture and dry matter contents.

The following sigmoid regression model was used to estimate biomass production (y) of the aboveground parts during sugarcane growth:

$$
y=\frac{a}{\left[1+\exp \left(\frac{x-x 0}{b}\right)\right]}
$$

where:

x0 - is the point of inflection (the day when the highest accumulation occurs); 
$\mathrm{x} \quad$ - is the time in days after planting (DAP);

a - is the highest value of " $y$ " obtained using the model (the value of the highest accumulation); and,

b - is the adjustment parameter that identifies the limit of sigmoidal behavior.

Using this model, the following accumulation phases were estimated from the model parameters: the first vegetative phase initiated at planting and lasting until " $\mathrm{x} 0-2 \mathrm{~b}$ "; the third reproductive phase, which commences at " $\mathrm{x} 0+2 \mathrm{~b}$ "; and the second vegetative phase, which corresponds to the intervening period between the first and the third phases (Oliveira et al., 2010).

During the growth of plants, the $\mathrm{N}$ concentration in the leaves +3 was determined at the same times as determinations of the aboveground dry mass. To determine the $\mathrm{N}$ concentration $\left(\mathrm{g} \mathrm{kg}^{-1}\right)$, used the middle third of 20 leaves (discarding the central rib) collected in the core area, which were subsequently dried in a forced circulation oven at $65^{\circ} \mathrm{C}$ to constant weight. The leaves were then ground in a ball mill (TECNAL - TE8100) and weighed on a precision balance $(0.01 \mathrm{~g})$. Extraction by sulfuric acid digestion and determination of $\mathrm{N}$ in plant tissues followed the methodology proposed by Sahrawat et al. (2002).

To determine the critical $\mathrm{N}$ dilution curve (CNDC), it was used the methodology and statistical parameters described by Oliveira et al. (2013), which uses the ADM ratio and the critical $\mathrm{N}$ contents in the diagnostic leaf for each collection performed. To determine the CNDC in plant cane, it was used the following allometric function described by Oliveira et al. (2013) (Eq. 2):

$$
\mathrm{N}_{\mathrm{cr}}=\mathrm{aMS}-\mathrm{b}
$$

where:

$\mathrm{N}_{\mathrm{cr}}$ - is the critical $\mathrm{N}$ concentration in the aboveground parts of the plant for a given biomass production, $\mathrm{g} \mathrm{kg}^{-1}$;

MS - is the aboveground dry matter mass, $\mathrm{Mg} \mathrm{ha}^{-1}$;

a - is the concentration in the diagnostic sheet required to produce $1 \mathrm{Mg} \mathrm{ha}^{-1}$; and,

b - is the dilution coefficient describing the relationship between the $\mathrm{N}$ content and the biomass of the aboveground parts.

At 315 DAP, the aboveground parts of plants growing in the core area of the plots were collected, and after cutting, the plants were stripped (removing the tops and leaves) and the stalks were weighed in the field using a digital dynamometer (precision of $0.05 \mathrm{~kg}$ ). The yield fresh stalk biomass was estimated in tons of stalk per hectare (TSH).

After weighing, a random sample of 10 stalks collected from each experimental plot were passed through a fodder chopper, and subsamples were collected for juice extraction and quantification of total recoverable sugar (TRS), according to the methodology of Fernandes (2003) and Carvalho et al. (2008). Subsequently, the sugar yield per hectare (TSuH) was calculated from the product of the TRS multiplied by the TSH.

The accumulation of dry biomass of the aboveground parts over time was analyzed based on a repeated measurement test, using the statistical package SAS Leaning 2.0, following the procedure for mixed models and selected covariance tests [AR
(1), Ante (1), ARH (1), ARMA (1), CS, CSH, HF, TOEP, Lin (1), UN] that presented the lowest value of the Akaike criterion (Wolfinger \& Chang, 1995).

The variables biomass production, productivity of industrialized stalks and sugars were assessed for normal distribution and homoscedasticity, and, when necessary, data transformations were performed. The variables TSH, TSuH and TRS were submitted to ANOVA, using a randomized block design under a $2 \times 7$ factorial arrangement. When a significant dose effect was observed, it was performed regression analysis, selecting the models that best fitted the data, which had the highest coefficients of determination $\left(\mathrm{R}^{2}\right)$ and significance for the parameters of the equation, as determined using the t-test $(\mathrm{p} \leq 0.05)$.

\section{Results AND Discussion}

It was observed differences between the two sugarcane varieties with respect to the accumulation of dry mass in aboveground parts (ADM) over time and adjusted these to the sigmoidal model, which allowed to identify three phases of vegetative development (Figure 1A). The first growth phase lasted 73 and 89 days for the varieties RB867515 and RB92579, respectively, and was characterized by low ADM production, with average gains of $5.85 \mathrm{Mg} \mathrm{ha}^{-1}$ for the two varieties.

For both varieties, it was obtained an average $12.01 \%$ ADM during the first growth phase; however, RB92579 showed a lower initial accumulation rate and longer duration with 15 days more growth and a production of $5.46 \mathrm{Mg} \mathrm{ha}^{-1}$ (Figure 1B).

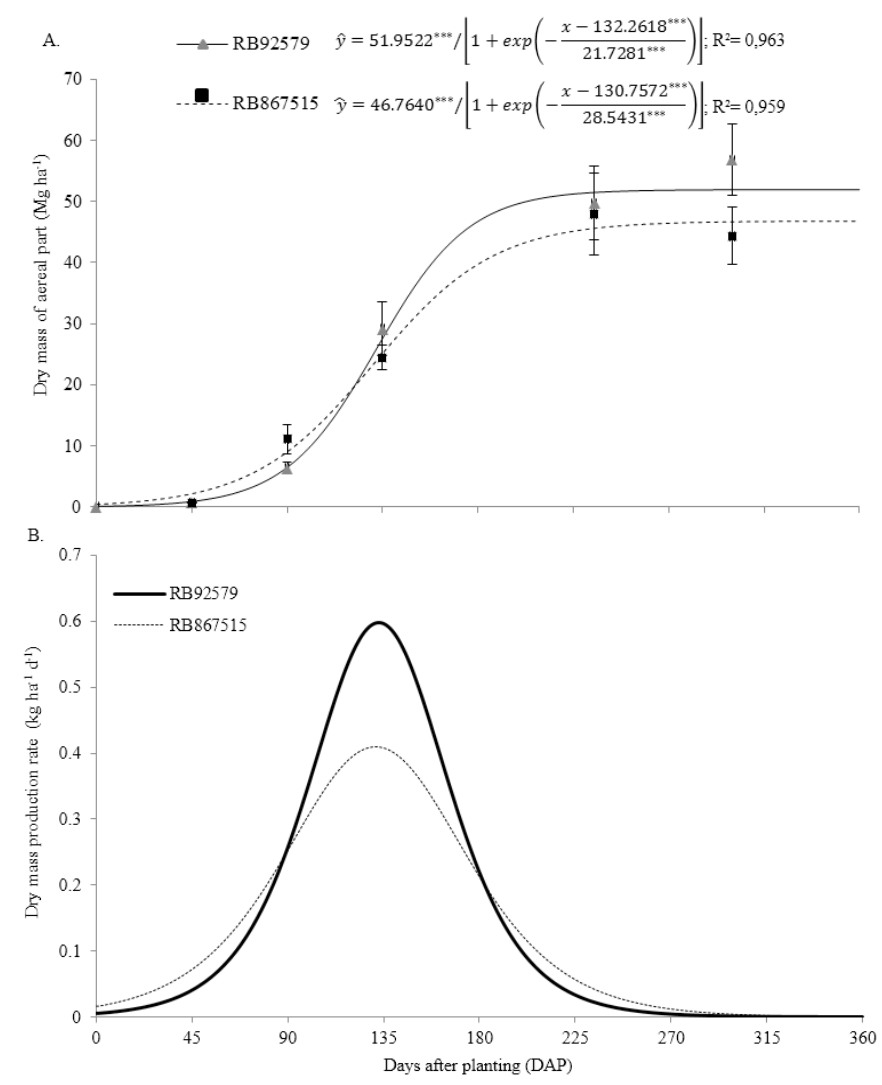

Figure 1. Dry mass accumulation curve (A) and dry mass production rate (DMPR) (B) of the aboveground parts of two sugarcane varieties (RB92579 and RB867515) during the plant cane cycle 
The observed differences in the timing of dry mass production between the two varieties during this early stage of growth is related to tillering. The RB92579 variety is characterized by the production of a larger number of tillers with smaller diameters and rates of growth, whereas the RB867515 variety produces lower number of tillers, which are larger in diameter and showed a more rapid initial growth (Almeida et al., 2008).

The second phase of growth was characterized by highest $\mathrm{ADM}$, with increases of 45.57 and $41.04 \mathrm{Mg} \mathrm{ha}^{-1}$ for varieties RB92579 and RB867515, respectively. At the end of this phase, which lasted 176 and 187 days for RB92579 and RB867515, respectively, was characterized by higher growth of the aboveground parts, more than $80 \%$ of the total dry biomass had accumulated in the aboveground parts of plants (Figure $1 \mathrm{~A})$. These observations are consistent with those reported by Oliveira et al. (2010) for irrigated varieties, which showed similar gains in the order of $83 \%$ during this phase.

The third and final phase of development was found to be associated with a relatively low contribution to ADM production, with an increase of only $0.26 \%$ during 38 days for RB867515 and 8.31\% during 35 days for RB92579 (Figure 1A). This phase is characterized by the maturation of plants, reduced growth and an increase in sugar content (Oliveira et al., 2017).

The longer duration of the first phase of growth with low ADM production, followed up by the second phase with shorter duration and a $46 \%$ higher biomass accumulation rate (Figures $1 \mathrm{~A}$ and B), enabled RB92579 to achieve a final ADM production that was $10.55 \mathrm{Mg} \mathrm{ha}^{-1}$ higher than that of RB867515 (Table 1).

It was also observed differences between the two varieties with respect to the dry mass production of the different aboveground components in response to $\mathrm{N}$ fertilization (Table 1), with the production of stalk dry mass being $23.64 \%$ higher in the RB92579 variety at 315 DAP. The varieties showed no significant differences with respect to their response to $\mathrm{N}$ fertilization, with an average increase of $58.19 \%$ up to a dose of $90 \mathrm{~kg} \mathrm{~N} \mathrm{ha}^{-1}$ (Figure 2B).

The dry mass yield of stalks is not limiting and made it possible to observe the plant cane response to the addition of increasing doses of $\mathrm{N}$ (Figure 2B). Inman-Bamber et al. (2002) also observed gains in dry mass production of plant cane stalks from 50 to $60 \mathrm{Mg} \mathrm{ha}^{-1}$ in response to increasing $\mathrm{N}$ fertilization,

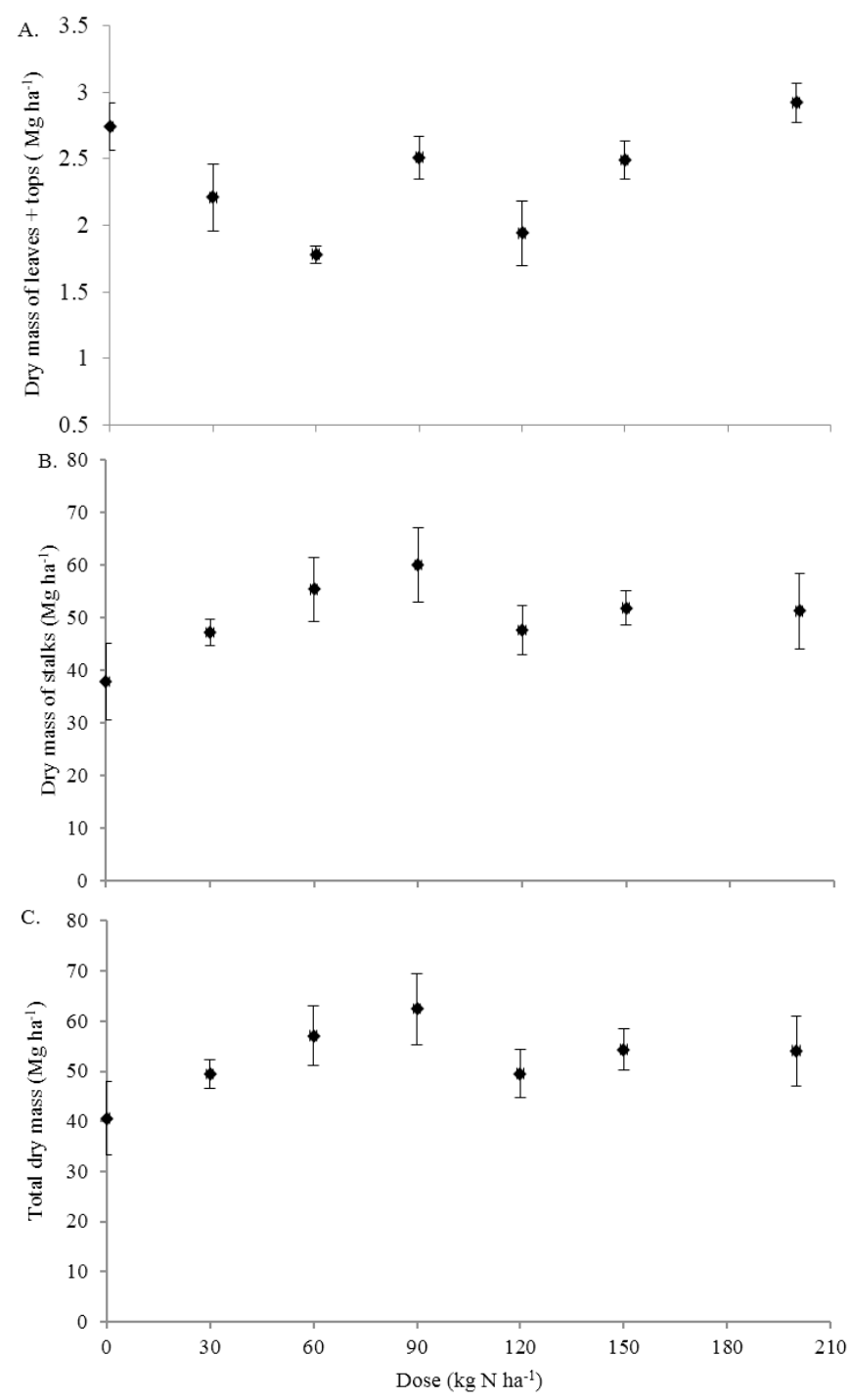

Figure 2. Dry mass of leaf + tops (A), stalk (B) and total plant (C) of the two sugarcane varieties RB92579 and RB867515 in the plant cane cycle as function of nitrogen doses

when plants are cultivated under adequate hydrological and nutritional conditions.

In contrast to stalks, the dry mass of the leaves and tops showed no difference between the varieties (Table 1) and was not influenced by $\mathrm{N}$ fertilization (Figure 2A). Thus, the

Table 1. Dry matter of the aboveground biomass components of the two sugarcane varieties at 315 days after planting in relation to nitrogen fertilization

\begin{tabular}{|c|c|c|c|c|c|c|}
\hline \multirow{3}{*}{$\begin{array}{c}\text { Dose } \\
\left(\mathrm{kg} \mathrm{ha}^{-1}\right)\end{array}$} & \multicolumn{2}{|c|}{ Green Leaf + Top } & \multicolumn{2}{|c|}{ Stalk } & \multicolumn{2}{|c|}{ Total } \\
\hline & RB92579 & RB867515 & RB92579 & RB867515 & RB92579 & RB867515 \\
\hline & \multicolumn{6}{|c|}{$\left(\right.$ Mg ha $\left.^{-1}\right)$} \\
\hline 0 & 2.48 & 3.01 & 40.91 & 34.71 & 43.40 & 37.72 \\
\hline 30 & 2.16 & 2.25 & 47.71 & 46.71 & 49.88 & 48.97 \\
\hline 60 & 1.59 & 1.96 & 58.24 & 52.41 & 59.84 & 54.37 \\
\hline 90 & 2.87 & 2.15 & 66.63 & 53.29 & 69.50 & 55.44 \\
\hline 120 & 1.89 & 2.00 & 54.29 & 40.91 & 56.18 & 42.91 \\
\hline 150 & 2.88 & 2.10 & 62.50 & 41.15 & 65.39 & 43.26 \\
\hline 200 & 2.56 & 3.27 & 57.71 & 44.66 & 60.28 & 47.94 \\
\hline \multirow[t]{2}{*}{ Average } & 2.35 & 2.39 & 55.43 & 44.83 & 57.78 & 47.23 \\
\hline & \multicolumn{2}{|c|}{$\mathrm{F}$} & \multicolumn{2}{|c|}{$\mathrm{F}$} & \multicolumn{2}{|c|}{$F$} \\
\hline Variety(V) & \multicolumn{2}{|c|}{$0.07^{\mathrm{ns}}$} & \multicolumn{2}{|c|}{$9.34^{\star \star \star}$} & \multicolumn{2}{|c|}{$9.20^{\star \star \star}$} \\
\hline Nitrogen (N) & \multicolumn{2}{|c|}{$3.35^{\star *}$} & \multicolumn{2}{|c|}{$2.33^{\star}$} & \multicolumn{2}{|c|}{$2.26^{\star}$} \\
\hline$V \times N$ & \multicolumn{2}{|c|}{$1,166^{\text {ns }}$} & \multicolumn{2}{|c|}{$0.54^{\mathrm{ns}}$} & \multicolumn{2}{|c|}{$0.59 \mathrm{~ns}$} \\
\hline CV (\%) & \multicolumn{2}{|c|}{23.38} & \multicolumn{2}{|c|}{22.40} & \multicolumn{2}{|c|}{21.46} \\
\hline
\end{tabular}

${ }^{\text {ns }}$ Not significant, ${ }^{*}, * *$, and ${ }^{* * *}$ - Significant at $\mathrm{p} \leq 0.10, \mathrm{p} \leq 0.05$ and $\mathrm{p} \leq 0.01$, respectively, by F test 
observed differences in the total ADM can be attributed to the responses of the stalk, which accounted for an average $95.45 \%$ of the total biomass produced.

Total DM production did not differ between the two varieties with respect to different $\mathrm{N}$ doses (Table 1). $\mathrm{N}$ fertilization of plant cane up to $90 \mathrm{~kg} \mathrm{~N} \mathrm{ha}^{-1}$ resulted in an average increase in DM of 53.55\% (Figure 2C), and of the two varieties, RB92579 was found to be more productive, showing a $22.33 \%$ higher aboveground biomass (Table 1 ).

On the basis of biomass production and $\mathrm{N}$ concentration in the +3 diagnostic leaves during plant cane growth, it was possible to determine the dilution curve of the critical $\mathrm{N}$ concentrations and the nitrogen utilization efficiency of the two varieties (Figure 3).

It is observed that the $\mathrm{N}$ concentration in leaves decreased exponentially with an increase in aboveground biomass and met the statistical criteria for determining the CNDC in the leaves +3 of plants (Figure 3). The critical N concentrations of 25.50, $16.75,14.03$ and $9.30 \mathrm{~g} \mathrm{~kg}^{-1}$ in the RB92579 variety were used for the production of biomass that varied from 0.61 to $51.6 \mathrm{Mg}$ ha $^{-1}$. Similarly, for the RB867515 variety, the $\mathrm{N}$ concentrations $25.55,16.81,12.83$ and $6.30 \mathrm{~g} \mathrm{~kg}^{-1}$ were used for the production of biomass that varied between 0.61 and $41.97 \mathrm{Mg} \mathrm{ha}^{-1}$.

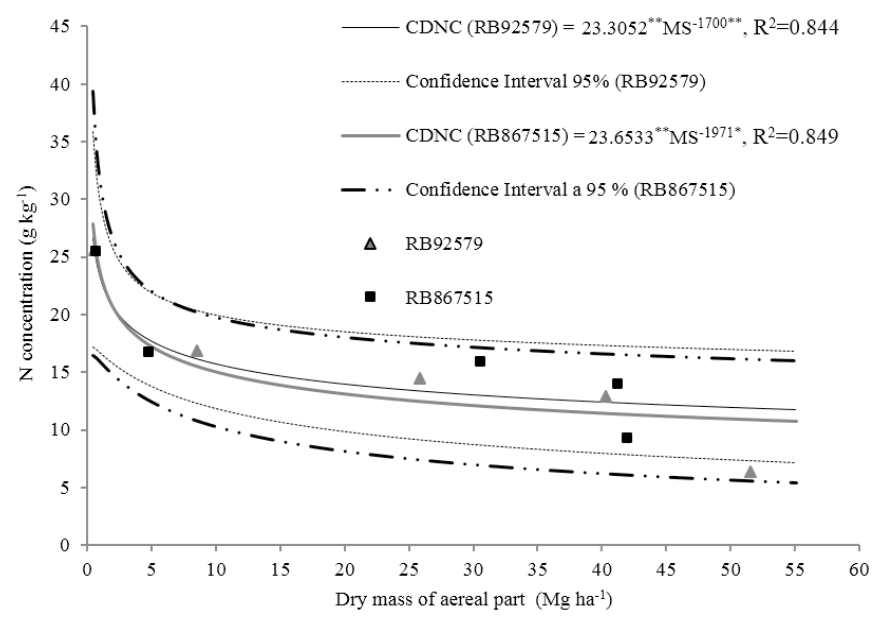

${ }^{* *}$ and ${ }^{* * *}$ Significant at $\mathrm{p} \leq 0.05$ and $\mathrm{p} \leq 0.01$, respectively, by $\mathrm{F}$ test

Figure 3. Critical nitrogen dilution curves (CNDC) of sugarcane varieties RB92579 and RB867515 as function of the dry biomass of the aboveground parts of plant cane
With production above $2 \mathrm{Mg} \mathrm{ha}^{-1}$ in the initial growth phase, the critical $\mathrm{N}$ contents estimated by CNDC were $20.71 \mathrm{~g} \mathrm{~kg}^{-1}$ in RB92579 and $20.63 \mathrm{~g} \mathrm{~kg}^{-1}$ in RB867515. At the end of the cycle, the critical $\mathrm{N}$ concentrations were 11.69 and $11.06 \mathrm{~g} \mathrm{~kg}^{-1}$, respectively, for the production of $57.78 \mathrm{Mg} \mathrm{ha}^{-1}$ in RB92579 and 47.23 $\mathrm{Mg} \mathrm{ha}^{-1}$ in RB867515 (Figure 3).

On the basis of estimates of the critical $\mathrm{N}$ concentrations obtained using CNDC, the nutritional status of $\mathrm{N}$ can be identified at any stage of sugarcane development in a preventive management, which makes it possible to evaluate the efficiency of the applied $\mathrm{N}$ fertilization and thereby to make corrective decisions, even before the periods of highest crop demand.

On the basis of CNDC, obtained critical N concentration estimates of 13.03 and $12.46 \mathrm{~g} \mathrm{~kg}^{-1}$ for the biomass productions $30.55 \mathrm{Mg} \mathrm{ha}^{-1}$ and $25.8 \mathrm{Mg} \mathrm{ha}^{-1}$ of the aboveground parts of the RB92579 and RB867515 varieties, respectively, which corresponded to the appropriate period (120 DAP) established for the nutritional assessment of sugarcane. These $\mathrm{N}$ concentrations are within the ranges indicated by nutritional assessment methods, which establish ranges of $13.0-15.0 \mathrm{~g} \mathrm{~kg}^{-1}$ using the Mathematical chance (MCh) method and 12.6 - 15.2 $\mathrm{g} \mathrm{kg}^{-1}$ using the Integrated Diagnosis and Recommendation System (DRIS) (Santos et al., 2013), thereby demonstrating the effectiveness of the equation obtained in estimating plant $\mathrm{N}$ nutritional status.

The coefficient "a" in the equation corresponds to the concentration of $\mathrm{N}$ in the aboveground parts for the production of $1 \mathrm{Mg} \mathrm{ha}^{-1}$, whereas the coefficient " $\mathrm{b}$ " indicates the critical $\mathrm{N}$ dilution intensity during the accumulation of DM with crop development. According to Adriolo et al. (2006), higher " $b$ " values (less negative) correspond to a lower dilution, and thus the estimated values of -0.164 and -0.197 for RB92579 and RB867515, respectively, indicate that the RB92579 variety is more efficient in utilizing $\mathrm{N}$, given that observed no difference in the critical concentrations of $\mathrm{N}$ during growth of the two varieties, whereas RB92579 yielded a higher production of ADM (Table 1).

As observed by Oliveira et al. (2013) in plant cane, the minimal variation in the $\mathrm{N}$ concentrations of leaf tissues at different $\mathrm{N}$ doses did not facilitate a determination of $\mathrm{N}$ concentrations that delimit the levels of deficiency and excess. These findings accordingly indicate that the ADM of plant cane

Table 2. Stalk productivity (TSH), sugar productivity (TSuH), and total recoverable sugar (TRS) of two sugarcane varieties in relation to nitrogen fertilization

\begin{tabular}{|c|c|c|c|c|c|c|}
\hline \multirow{3}{*}{ Dose of $N$} & \multicolumn{2}{|c|}{ TSH } & \multicolumn{2}{|c|}{ TSuH } & \multicolumn{2}{|c|}{ TRS } \\
\hline & RB92579 & RB867515 & RB92579 & RB867515 & RB92579 & RB867515 \\
\hline & \multicolumn{4}{|c|}{$\left(\mathrm{Mg} \mathrm{ha}^{-1}\right)$} & \multicolumn{2}{|c|}{$\left(\mathrm{kg} \mathrm{t}^{-1}\right)$} \\
\hline 0 & 101.46 & 92.94 & 16.96 & 17.58 & 164.5 & 171.77 \\
\hline 30 & 109.92 & 107.23 & 17.19 & 18.90 & 155.48 & 172.43 \\
\hline 60 & 115.27 & 109.32 & 19.56 & 17.17 & 166.21 & 168.29 \\
\hline 90 & 114.14 & 115.91 & 17.53 & 19.18 & 153.08 & 163.92 \\
\hline 120 & 115.77 & 117.14 & 19.37 & 17.42 & 165.57 & 148.33 \\
\hline 150 & 124.71 & 108.30 & 19.67 & 18.38 & 151.99 & 165.25 \\
\hline 200 & 122.32 & 103.37 & 17.92 & 17.90 & 153.74 & 158.97 \\
\hline \multirow[t]{2}{*}{ Average } & 114.80 & 107.74 & 18.32 & 18.08 & 158.65 & 164.14 \\
\hline & \multicolumn{2}{|c|}{$\mathrm{F}$} & \multicolumn{2}{|c|}{$\mathrm{F}$} & \multicolumn{2}{|c|}{$F$} \\
\hline Variance (V) & \multicolumn{2}{|c|}{$8.24^{\star \star \star}$} & \multicolumn{2}{|c|}{$0.85^{\text {ns }}$} & \multicolumn{2}{|c|}{$3.45^{\star}$} \\
\hline Dose (D) & \multicolumn{2}{|c|}{$4.62^{\star \star \star}$} & \multicolumn{2}{|c|}{$0.32^{\text {ns }}$} & \multicolumn{2}{|c|}{$1.60^{\text {ns }}$} \\
\hline$V \times D$ & \multicolumn{2}{|c|}{$1.46^{\text {ns }}$} & \multicolumn{2}{|c|}{$2.36^{\star}$} & \multicolumn{2}{|c|}{$1.97^{\star}$} \\
\hline CV & \multicolumn{2}{|c|}{7.89} & \multicolumn{2}{|c|}{8.14} & \multicolumn{2}{|c|}{6.58} \\
\hline
\end{tabular}

${ }_{\text {ns }}$ Not significant, ${ }^{* * *},{ }^{* *}$, and ${ }^{\star}$ - Significant at $\mathrm{p} \leq 0.01, \mathrm{p} \leq 0.05$, and $\mathrm{p} \leq 0.10$, respectively 
production is significantly influenced by minimal variations in the critical range of $\mathrm{N}$ in sugarcane tissues.

Although the CNDC values determined in the present study enabled to efficiently estimate the critical $\mathrm{N}$ concentrations for maximum ADM yield during the plant cane cycle for both examined varieties, in order to verify the reliability of both equations used, would need to perform validations involving an assessment of more data using varieties that have developed under different climatic and soil conditions, as well as under alternative management practices with varying $\mathrm{N}$ availability.

Fertilization with $\mathrm{N}$ increased the yield of stalks (TSH), but there are no significant differences between the two varieties (Table 2). The data adjusted to the quadratic polynomial model, were able to determine that plant cane responds positively to $\mathrm{N}$ fertilization until an estimated dose of $129.45 \mathrm{~kg} \mathrm{~N} \mathrm{ha}^{-1}$, with an increment of $18.43 \mathrm{Mg} \mathrm{ha}^{-1}(18.66 \%)$ and estimated maximum yield of $117.19 \mathrm{Mg} \mathrm{ha}^{-1}$ of stalks (Figure 4A).

From the two assessed varieties, RB92579 showed to be more productive $(6.55 \%)$, which what stands out the value

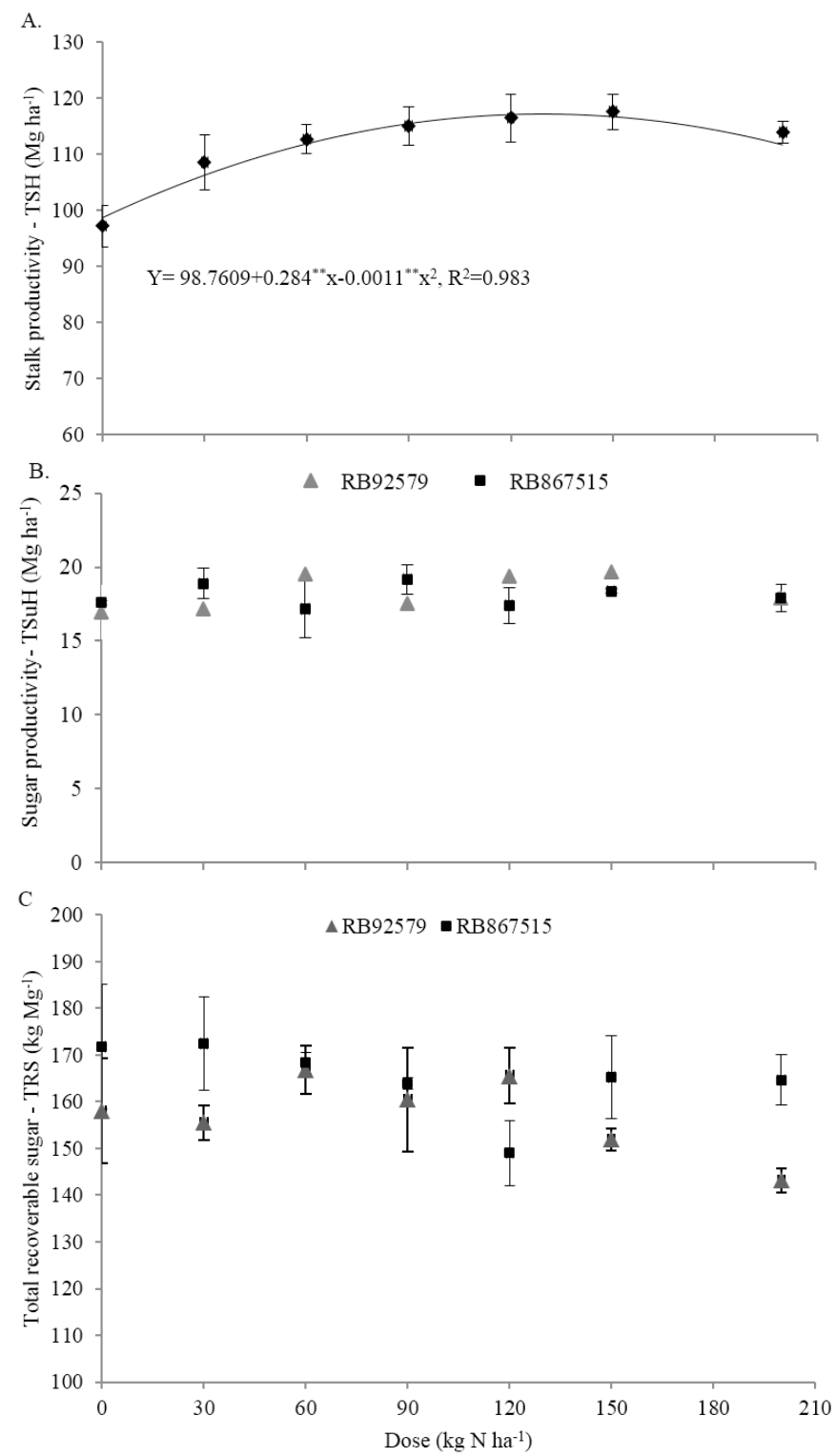

Figure 4. Stalk yield (TSH) (A), sugar yield (TSuH) (B) and total recoverable sugar (TRS) (C) of two sugarcane varieties (RB92579 and RB867515) in the plant cane cycle as function of nitrogen doses of using CNDC and indicates the greater efficiency of this variety with respect to the conversion of absorbed $\mathrm{N}$ fertilizer into TSH, given that the two varieties showed no significant differences in their response to $\mathrm{N}$ fertilization, although RB92579 obtained a higher final productivity.

In Brazil, research on the effects of $\mathrm{N}$ fertilization in sugarcane plants is mainly conducted in the South Central region of the country and has indicated uncertainties regarding the application of $\mathrm{N}$ in plant cane cultivation, and it has been suggested that nitrogen fertilization should be limited to

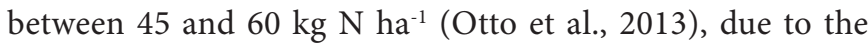
existence of secondary $\mathrm{N}$ sources, such as the biological fixation of $\mathrm{N}$, mineralization of soil organic matter, and $\mathrm{N}$ reserves present in the stalks seeds (Trivelin et al., 2002). However, the results obtained in the present study indicate that plant cane grown in the Northeast of Brazil responds positively to $\mathrm{N}$ fertilization at doses higher than $100 \mathrm{~kg} \mathrm{~N} \mathrm{ha}^{-1}$.

It is assumed that the growth increases observed in response to the application of high doses of $\mathrm{N}$ in sugarcane cultivated in the Northeast of Brazil are related to the varieties used and to the availability of $\mathrm{N}$ in the soils in which the sugarcane is cultivated. Currently, the highest percentages of the sugarcane areas in the Northeast of Brazil are cultivated with the varieties RB92579 and RB867515, which in addition to being more productive are also more demanding of $\mathrm{N}$ (Oliveira et al., 2016).

Furthermore, in addition to the cultivation of more $\mathrm{N}$ demanding varieties, the lower productivity and the practice of burning crops in the Northeast region of Brazil reduces the contribution of organic matter added to the soil on plant cane. As $\mathrm{N}$ mineralization of soil organic matter is the main source of mineral $\mathrm{N}$ for non-leguminous plants (Otto et al., 2013), the availability of $\mathrm{N}$ for plant cana is reduced, and thus it is necessary to provide higher quantities by mineral $\mathrm{N}$ fertilizers.

With respect to sugar productivity (TSuH) and total recoverable sugar (TRS), it was detected an interaction between variety and $\mathrm{N}$ dose (Table 2 ). The varieties showed a difference in TSuH only in response to the application of $150 \mathrm{~kg} \mathrm{~N} \mathrm{ha}^{-1}$, with RB92579 being the more productive variety, yielding an additional $1.29 \mathrm{Mg} \mathrm{ha}^{-1}$ of sugar (Figure 4B). For both varieties, detected an increase in the TSuH with an increasing level of $\mathrm{N}$ fertilization, with the highest gains in RB92579 and RB867515 being observed in response to the application of 60 and $30 \mathrm{~kg} \mathrm{~N} \mathrm{ha}^{-1}$, respectively (Figure 4B).

In contrast, it was found that $\mathrm{N}$ fertilization reduced the TRS contents of the two varieties, mainly in response to higher $\mathrm{N}$ doses (Figure 4C). For RB867515 and RB92579, the highest reductions were observed in plants treated with $\mathrm{N}$ doses higher than $120 \mathrm{~kg} \mathrm{~N} \mathrm{ha}^{-1}$, showing losses of 12.80 and $12.56 \mathrm{~kg} \mathrm{t}^{-1}$, respectively (Figure $4 \mathrm{C}$ ).

A similar reduction in the sucrose content of sugarcane stalks at high $\mathrm{N}$ fertilization levels has also been observed by Rhein et al. (2016) and has been demonstrated to be associated with a reduction in stalk dry mass content in response to an increase in applied N (Muchow et al., 1996). An enhanced water content in stalks reduces sucrose concentration, and thus TRS by conversion to simple sugars aimed at greater vegetative growth (Bahrani et al., 2009). 


\section{Conclusions}

1. The dry mass production of the aboveground parts (ADM) of the varieties RB92579 and RB867515 showed a sigmoidal behavior during plant cane growth, with $12 \%$ of plant cane production occurring between 89 and 73 days after planting, respectively, and with more than $90 \%$ of the final dry biomass not being produced until after 8.5 months of growth.

2. The critical $\mathrm{N}$ concentrations of leaves showed an exponential reduction with an increase in ADM production, making it possible to use the critical nitrogen dilution curve to identify the critical concentrations of $20.67+0.05 \mathrm{~g} \mathrm{~N} \mathrm{~kg}^{-1}$ at the beginning of growth and $11.48+0.42 \mathrm{~g} \mathrm{~N} \mathrm{~kg}^{-1}$ at the ripening stage of the varieties RB92579 and RB867515.

3. Plant cane responded positively to $\mathrm{N}$ fertilization, with an increase of $18.66 \%$ of TSH in response to the application of up to $129.45 \mathrm{~kg} \mathrm{~N} \mathrm{ha}^{-1}$ and gains of $9.10 \%$ and $15.33 \%$ in sugar productivity per hectare with the addition of 30 and $60 \mathrm{~kg} \mathrm{~N} \mathrm{ha-1}$ in the varieties RB867515 and RB92579, respectively.

\section{ACKNOWLedgements}

Gratefully acknowledge Coordenação de Aperfeiçoamento de Pessoal de Nível Superior (CAPES) for funding the present study, the Universidade Federal Rural de Pernambuco (UFRPE) for the provision of laboratory facilities, and São José Sugarcane mill for the personal and financial support for the installation, realization, and harvesting activities associated with this study.

\section{Literature Cited}

Adriolo, J. L.; Bisognin, D. A.; Paula, A. L.; Paula, F. L. M.; Godoi, R. S.; Barros, G. T. Curva crítica de diluição de nitrogênio do cultivar Asterx de batata. Pesquisa Agropecuária Brasileira, v.41, p.11791184, 2006. https://doi.org/10.1590/S0100-204X2006000700015

Almeida, A. C. S.; Souza, J. L.; Teodoro, I.; Barbosa, G. V. S.; Moura Filho, G.; Ferreira Júnior, R. A. Desenvolvimento vegetativo e produção de variedades de cana-de-açúcar em relação à disponibilidade hídrica e unidades térmicas. Ciência e Agrotecnologia, v.32, p.1441-1448, 2008. https://doi.org/10.1590/ S1413-70542008000500013

Alvares, C. A.; Stape, J. L.; Sentelhas, P. C.; Gonçalves, J. L. M.; Sparovek, G. Köppen's climate classification map for Brazil. Meteorologische Zeitschrift, v.22, p.721-728, 2013. https://doi. org/10.1127/0941-2948/2013/0507

Bahrani, M. J.; Shomeili, M.; Zande-Parsa, S. H.; Kamgar-Haghighi, A. Sugarcane responses to irrigation and nitrogen in subtropical Iran. Iran Agricultural Research, v.28, p.17-26, 2009.

Carvalho, C. M. de; Azevedo, H. M. de; Dantas Neto, J.; Melo, E. P. de; Silva, C. T. S. da; Gomes Filho, R. R. Resposta dos parâmetros tecnológicos da terceira folha de cana-de-açúcar submetida a diferentes níveis de irrigação. Revista Brasileira de Ciências Agrárias, v.3, p.337-342, 2008. https://doi.org/10.5039/agraria. v3i4a113
EMBRAPA - Empresa Brasileira de Pesquisa Agropecuária. Manual de métodos de análise de solos. 3.ed. Brasília: Embrapa Informação Tecnológica, 2017. 575p.

Fernandes, A. C. Cálculos na agroindústria da cana-de-açúcar. Piracicaba: Sociedade das Técnicos Açucareiro e Alcooleiros do Brasil, 2003. 193p.

Fortes, C.; Trivelin, P. C. O.; Vitti, A. C.; Otto, R.; Franco, H. C. J.; Faroni, C. E. Stalk and sucrose yield in response to nitrogen fertilization of sugarcane under reduced tillage. Pesquisa Agropecuária Brasileira, v.48, p.88-96, 2013. https://doi. org/10.1590/S0100-204X2013000100012

Franco, H. C. J.; Otto, R.; Vitti, A. C.; Faroni, C. E.; Oliveira, E. C. de A.; Fortes, C.; Ferreira, A. A.; Kölln, O. T.; Garside, A. L.; Trivelin, P. C. O. Residual recovery and yield performance of nitrogen fertilizer applied at sugarcane planting. Scientia Agricola, v.72, p.528-534, 2015. https://doi.org/10.1590/01039016-2015-0170

Franco, H. C. J.; Trivelin, P. C. O.; Faroni, C. E.; Vitti, A. C.; Otto, R. Stalk yield and technological attributes of planted cane as related to nitrogen fertilization. Scientia Agricola, v.67, p.579-590, 2010. https://doi.org/10.1590/S0103-90162010000500012

Inman-Bamber, N. G.; Muchow, R. C.; Robertson, M. J. Dry partitioning of sugarcane in Australia and South Africa. Field Crops Research, v.76, p.71-84, 2002. https://doi.org/10.1016/ S0378-4290(02)00044-8

Muchow, R. C.; Robertson, M. J.; Wood A. W.; Keating, B. A. Effect of nitrogen on the time-course of sucrose accumulation in sugarcane. Fild Crops Research, v.47, p.143-153, 1996. https:// doi.org/10.1016/0378-4290(96)00022-6

Oliveira, E. C. A.; Oliveira, R. I.; Andrade, B. M. T.; Freire, F. J.; Lira Junior, M. A.; Machado, P. R. Crescimento e acúmulo de matéria seca em variedades de cana-de-açúcar cultivada sob irrigação plena. Revista Brasileira de Engenharia Agrícola e Ambiental, v.14, p.951-960, 2010. https://doi.org/10.1590/S141543662010000900007

Oliveira, E. C. A.; Gava, G. J. C.; Trivelin, P. C. O.; Otto, R.; Franco, H. C. J. Determining a critical nitrogen dilution curve for sugarcane. Journal of Plant Nutrition Soil Science, v. 176, p.712-723, 2013.

Oliveira, R. I.; Medeiros, M. R. F. A. de; Freire, C. S.; Freire, F. J.; Simões Neto, D. E.; Oliveira, E. C. A. Nutrient partitioning and nutritional requirement in sugarcane. Australian Journal of Crop Science, v.10, p.69-75, 2016.

Oliveira, D. C.; Oliveira, M. W.; Pereira, M. G.; Gomes, T. C. A.; Silva, V. S. G.; Oliveira, T. B. A. Stalk productivity and quality of three sugarcane varieties at the beginning, in the middle, and at the end of the harvest. African Journal of Agricultural Research, v.12, p.260-269, 2017. https://doi.org/10.5897/AJAR2016.11789

Otto, R.; Mulvaney, R. L.; Khan, S. A.; Trivelin, P. C. O. Quantifying soil nitrogen mineralization to improve fertilizer nitrogen management of sugarcane. Biology and Fertility of Soils, v.49, p.893-904, 2013. https://doi.org/10.1007/s00374-013-0787-5

Rhein A.F.L.; Pincelli, R.P.; Arantes, M.T.; Dellabiglia,W.J.; Kölln, O.T.; Silva, M. A. Technological quality and yield of sugarcane grown under nitrogen doses via subsurface drip fertigation. Revista Brasileira de Engenharia Agrícola e Ambiental, v.20, p.209-214, 2016. https://doi.org/10.1590/1807-1929/agriambi. v20n3p209-214 
Sahrawat, K. L.; Kumar, G. R.; Murthy, K. V. S. Sulfuric acid-selenium digestion for multi-element analysis in a single plant digest. Communications in Soil Science and Plant Analysis, v.33, p.37573765, 2002. https://doi.org/10.1081/CSS-120015920

Santos, E. F.; Donha, R. M. A.; Araújo, C. M. M.; Lavres Junior, J.; Camacho, M. A. Normal nutrient ranges for sugarcane by the methods ChM, DRIS and CND and critical level by reduced normal distribution. Revista Brasileira de Ciência do Solo, v.37, p.16511658, 2013. https://doi.org/10.1590/S0100-06832013000600021

Silveira, L. C. I. da; Kist, V.; Paula, T. O. M. de; Barbosa, M. H. P.; Oliveira, R. A. de; Daros, E. Adaptabilidade e estabilidade fenotípica de genótipos de cana-de-açúcar no estado de Minas Gerais. Ciência Rural, v.42, p.587-593, 2012. https://doi. org/10.1590/S0103-84782012000400002
Trivelin, P. C. O.; Vitti, A. C.; Oliveira, M. W.; Gava, G. J. C.; Sarriés, G. A. Utilização de nitrogênio e produtividade da cana-de-açúcar (cana planta) em solos arenoso com incorporação de resíduos da cultura. Revista Brasileira de Ciência do Solo, v.26, p.637-646, 2002. https://doi.org/10.1590/S0100-06832002000300008

Vale, D. W. do; Prado, R. de M.; Avalhães, C. C.; Hojo, R. H. Omissão de macronutrientes na nutrição e no crescimento da cana-deaçúcar cultivada em solução nutritiva. Revista Brasileira de Ciências Agrárias, v.6, p.189-196, 2011. https://doi.org/10.5039/ agraria.v6i2a550

Wolfinger, R.; Chang, M. Comparing the SAS ${ }^{\circledR}$ GLM and MIXED Procedures for Repeated Measures, 1995. Available on: <http:// support.sas.com/rnd/app/stat/papers/mixedglm.pdf >. Accessed on: jan. 2017. 